\title{
Guideline for Survey, Investigation, and Design of Black Spot Location (SID-BSL) and Its Application in Lampung Province, Indonesia
}

\author{
Susilo, B.H.1
}

\begin{abstract}
In connection with the government's obligation to take responsibility for ensuring the safety of traffic and road transport for road users, it is necessary to conduct Surveys, Investigations, and Design of Black Spot Location (SID-BSL) to reduce traffic accident. Hence a guideline in conducting SID-BSL is needed. In this study, the author compiled a simple technique of prioritization for SID-BSL procedure and applies it to a research on National Roads in the Lampung Province. The technique of prioritization is simplified with four phase activities namely Preparation, Initial Analysis, Detail Survey, and Detail Analysis. The analysis technique is based on the ranking of Black Spot Locations using weighted accident number (WAN). Application procedure is applied on 237 events of accident on the National Roads in Lampung Province resulting five selected BSLs to be treated according to the availability of funds.
\end{abstract}

Keywords: EAN analysis; guideline of SID-BSL; prioritization technique; weighted accident number.

\section{Introduction}

Traffic accident is one of the enormous problems faced by the Indonesian Government. Data from the Police Department shows that each year more than 30,000 people died in traffic accidents and over 70,000 people suffered permanent injuries that cause many people become invalid and unable to work properly [1].

In Indonesia, increasing number of vehicles and human errors become major factors in the increase in traffic accidents. Data from the Police Department showed that in 2011, there were 109,776 accidents causing the deaths of 31,185 people, while in 2012 there were 109,038 accidents causing the deaths of 27,441 people, with the potential socio-economic loss of about 203 trillion to 217 trillion IDR per year (2.9\% - 3.1\% of Indonesian GDP) or around 17.5 billion USD [2].

In connection with the responsibility of the government to ensure the safety of traffic and road transport for road users [3], it is necessary to conduct Surveys, Investigations, and Design concerning Black Spot Locations [4].

1. Civil Engineering Department, Maranatha Christian University, Jl. Suria Sumantri 65, Bandung 40164, INDONESIA. E-mail: budiharsus@yahoo.com

Note: Discussion is expected before June, $1^{\text {st }} 2016$, and will be published in the "Civil Engineering Dimension" volume 18, number 2, September 2016.

Received 12 February 2015; revised 18 February 2015; accepted 12 March 2016.
Therefore, there is a need to develop a guideline in conducting Surveys, Investigations, and Design Concerning Black Spot Location (SID-BSL) [5]. Black Spot Location (BSL) is the location that has a high accident rate in the same place and relatively at the same time frame [6]. The guideline is expected to reduce traffic accidents. The main problems in the research are:

1. How to prioritize BSL treatments based on secondary data from the Police, Department of Transportation, and Department of Highways, and the availability of funds.

2. How to develop this prioritization technique into a guideline for BSL Treatments, from Surveys, Investigations, and Design up to Detail Engineering Design and Construction Cost Estimation for selected BSL.

The objective of this research is to develop a guideline for Black Spot Locations treatments, from Survey, Investigations, and Design up to Detail Engineering Design and Construction Cost Estimation for selected BSL.

\section{Technical Requirements}

Black Spot Location Identification based on Accident Frequency

Identification of 20 or at least ten BSLs is based on the highest number of accident. The BSL should at least has two events of accident in a year. The data is taken from previous years and synchronized with secondary data from Police or Department of Transportation. 


\section{Black Spot Location Ranking Technique}

Technique of identifying the ranking of crash site is carried out by determining the Weighted Accident Number (WAN). There are several types or degrees of accident based on the victim severities so the accident number needs to be weighted by Equivalent Accident Number (EAN) to become WAN. EAN is a numeric economic scale to weigh the degree of accidents. It is calculated by comparing the estimated economic loss caused by various degrees of accident, namely death victims (DV), serious injuries (SI), light injuries (LI), or damaged property (DP). There are several EAN values suggested as shown in Table 1.

Using the rationalized average value of EAN shown in Table 1, the WAN value of a location is calculated as follows:

$$
\begin{aligned}
W A N= & \text { No. of } D V \times E A N_{D V}+\text { No. of } S I \times E A N_{S I}+ \\
& \text { No. of } L I \times E A N_{L I}+\text { No. of } D P \times E A N_{D P}
\end{aligned}
$$

\section{Number of Selected Black Spot Locations}

The number of selected BSL is determined by counting the number of BSL with WAN higher than the average in all BSL. The calculation of the average value of WAN (UCL) from $n$ number of BSL is as follows:

$$
U C L=\frac{\sum W A N}{n}
$$

The number of selected BSL that will be treated also depends on the availability of funds.

\section{Detail Engineering Design}

Detail Engineering Design, which is also referred to as Final Engineering Design, is a set of detailed technical design drawings related to the black spot location or accident-prone location treatments [7].

\section{Estimation of Construction Cost}

Estimation of construction cost is based on the various treatments of the Black Spot Location selected. The method of calculating the cost of a volume or quantity is derived from the design drawings multiplied by the unit cost (which consists of wages, tools, and materials) so that the amount of the estimated cost can be calculated [8].

\section{General Procedures}

The procedure consists of four stages, which can be seen in Figure 1.

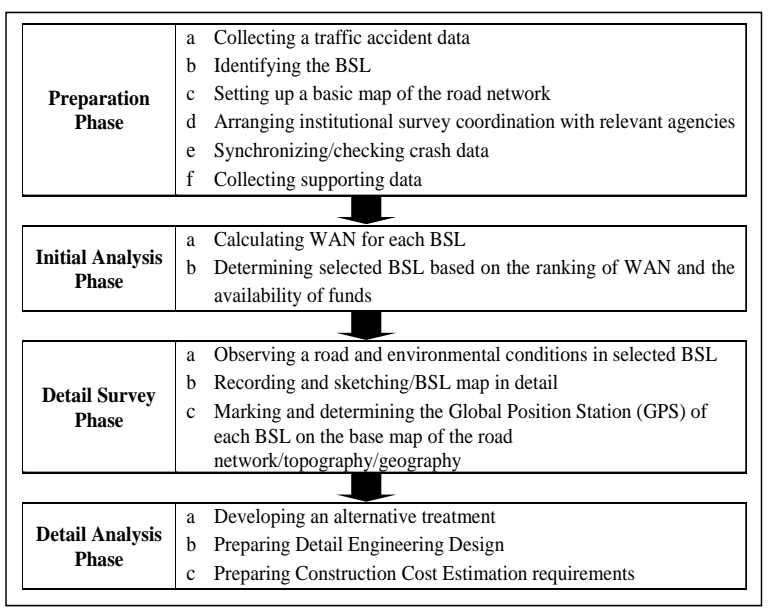

Figure 1. Stages of Procedure of SID-BSL

\section{Case Study}

The procedure is applied on the National Roads in Lampung Province as a practical example. There were 237 events of accidents occurred during January 2014 to August 2014 [9]. Due to limited funds, the government has to prioritize which BSLs should be treated first.

\section{Preparation Phase}

Several things have to be prepared in the implementation of SID-BSL, namely:

a. Collecting traffic accident data for at least the previous year. The accident data can be obtained from various sources, for example from the

\begin{tabular}{|c|c|c|c|c|c|c|c|c|c|}
\hline Degree of & USA & $\begin{array}{l}\text { Puslitbang } \\
\text { Jalan }\end{array}$ & $\begin{array}{l}\text { Ditjen } \\
\text { Hubdat }\end{array}$ & $\begin{array}{l}\text { Ditjen Hubdat } \\
\text { (Recently) }\end{array}$ & Polri & SP & BHS & $\begin{array}{l}\text { Average Value in } \\
\text { Indonesia }\end{array}$ & $\begin{array}{c}\text { Rationalized } \\
\text { Average Value }\end{array}$ \\
\hline Accident & (1) & (2) & (3) & (4) & (5) & (6) & (7) & $\begin{aligned}(8)= & ((2)+(3)+(4)+(5) \\
& +(6)+(7)) / 6\end{aligned}$ & (9) \\
\hline DV & 900 & 12 & 12 & 12 & 10 & 325 & 300 & 111 & 100 \\
\hline SI & 100 & 3 & 6 & 7 & 5 & 20 & 50 & 15 & 20 \\
\hline $\mathrm{LI}$ & 10 & 3 & 3 & 3 & 1 & 6 & 5 & 3 & 5 \\
\hline $\mathrm{DP}$ & 1 & 1 & 1 & 1 & 1 & 1 & 1 & 1 & 1 \\
\hline
\end{tabular}
internet.

Table 1. Equivalent Accident Number (EAN)

Descriptions: Puslitbang Jalan = Institute Of Road Engineering Ministry of Public Works and Housing; Ditjen Hubdat $=$ Directorate General of Land Transportation; Polri = Indonesian National Police; SP = Sigit Priyanto [10]; BHS = Budi Hartanto Susilo [11]. 
b. Processing obtained data of accidents to identify the list of ten to 20 worst BSL. The list of the worst crash sites was obtained by referring to technical requirements to identify Black Spot Locations based on the frequency of accidents.

c. Setting up a basic map of the road network available according to an investigation plan that will be conducted.

d. Arranging institutional survey coordination with relevant agencies, including collecting secondary data from the relevant agencies.

e. Synchronizing data of accidents in point $b$ with data of accidents obtained from the relevant authorities or through coordination with related agencies. If there are differences in the worst location, the ranking of worst crash site should be repeated.

f. Collecting supporting primary or secondary data, such as average daily traffic volume on road sections at the identified crash site.

From the preparation phase, there are 11 identified BSLs on National Roads in Lampung Province [12].

\section{Initial Analysis Phase}

The initial analysis phase consists of ranking process of 11 identified BSLs based on the survey on the degrees of accident and WAN as illustrated in Table 2 .

Table 2. BSL Ranking Based on WAN

\begin{tabular}{|c|c|c|c|c|c|c|c|c|}
\hline \multirow{2}{*}{ No. } & \multirow{2}{*}{ BSL } & \multirow{2}{*}{ No. of Accident } & \multicolumn{3}{|c|}{ No. of Victims } & \multirow{2}{*}{ Calculation } & \multirow{2}{*}{ WAN } & \multirow{2}{*}{ Rank } \\
\hline & & & DV & SI & $\mathrm{LI}$ & & & \\
\hline$(1)$ & $(2)$ & (3) & $(4)$ & $(5)$ & (6) & $(8)=(4) * 100+(5) * 20+(6)^{*} 5+(3) * 1$ & $(8)$ & (9) \\
\hline 1 & Jalinteng KM 66 & 2 & 0 & 2 & 0 & $0+40+0+2$ & 42 & 9 \\
\hline 2 & Jalinteng KM 72 & 2 & 1 & 2 & 0 & $100+40+0+2$ & 142 & 5 \\
\hline 3 & Jalinteng KM 192 & 1 & 1 & 0 & 0 & $100+0+0+1$ & 101 & 6 \\
\hline 4 & Jalinteng KM 19 & 2 & 1 & 2 & 1 & $100+40+5+2$ & 147 & 4 \\
\hline 5 & Jalinteng KM 14 & 3 & 2 & 1 & 1 & $200+20+5+3$ & 228 & 2 \\
\hline 6 & Jalinteng KM 88 & 1 & 0 & 1 & 0 & $0+20+0+1$ & 21 & 11 \\
\hline 7 & Jalinteng KM 21 & 2 & 2 & 0 & 0 & $200+0+0+2$ & 202 & 3 \\
\hline 8 & Jalinteng KM 23 & 2 & 0 & 2 & 1 & $0+40+5+2$ & 47 & 8 \\
\hline 9 & Jalinteng KM 38 & 3 & 2 & 2 & 1 & $200+40+5+3$ & 248 & 1 \\
\hline 10 & Jalintim KM 90 & 1 & 1 & 0 & 0 & $100+0+0+1$ & 101 & 7 \\
\hline 11 & Jalintim KM 128 & 1 & & $\begin{array}{c}2 \\
\text { JAN }\end{array}$ & 0 & $0+40+0+1$ & $\begin{array}{c}41 \\
1320\end{array}$ & 10 \\
\hline
\end{tabular}

Description: Jalinteng $=$ Central Trans-Sumatra Highway; Jalintim = East Trans-Sumatra Highway; Jalinbar $=$ West Trans-Sumatra Highway.

Table 3. Examples of Detail Survey Results on Selected BSLs [13]

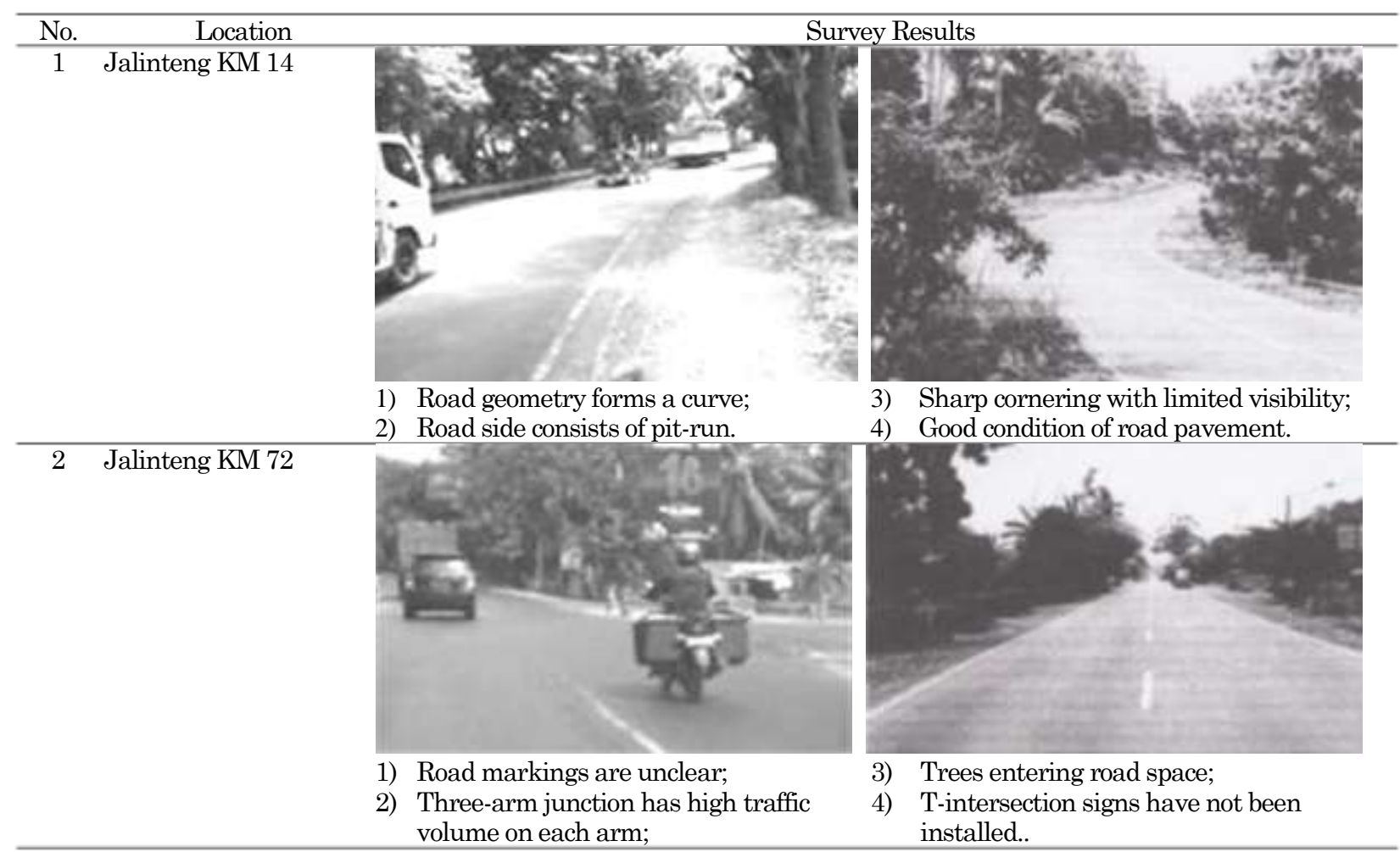


Using the Equation 2, the UCL $=1320 / 11=120$. The selected BSL in Lampung Province should have WAN value above 120, namely: Jalinteng KM 38 $(\mathrm{WAN}=248)$, Jalinteng $\mathrm{KM} 14(\mathrm{WAN}=228)$, Jalinteng KM 21 (WAN = 202), Jalinteng KM 19 (WAN = 147), Jalinteng KM $72(\mathrm{WAN}=142)$.

\section{Detail Survey Phase}

Detail survey of the BSL is done as follows:

a. Observing road and environmental conditions on selected BSLs using a video camera or a photo, as illustrated in Table 3.

b. Recording and sketching each selected BSL maps in detail.

c. Marking and determining the GPS of each selected BSL on the base map of the road network/topography/geography [14].
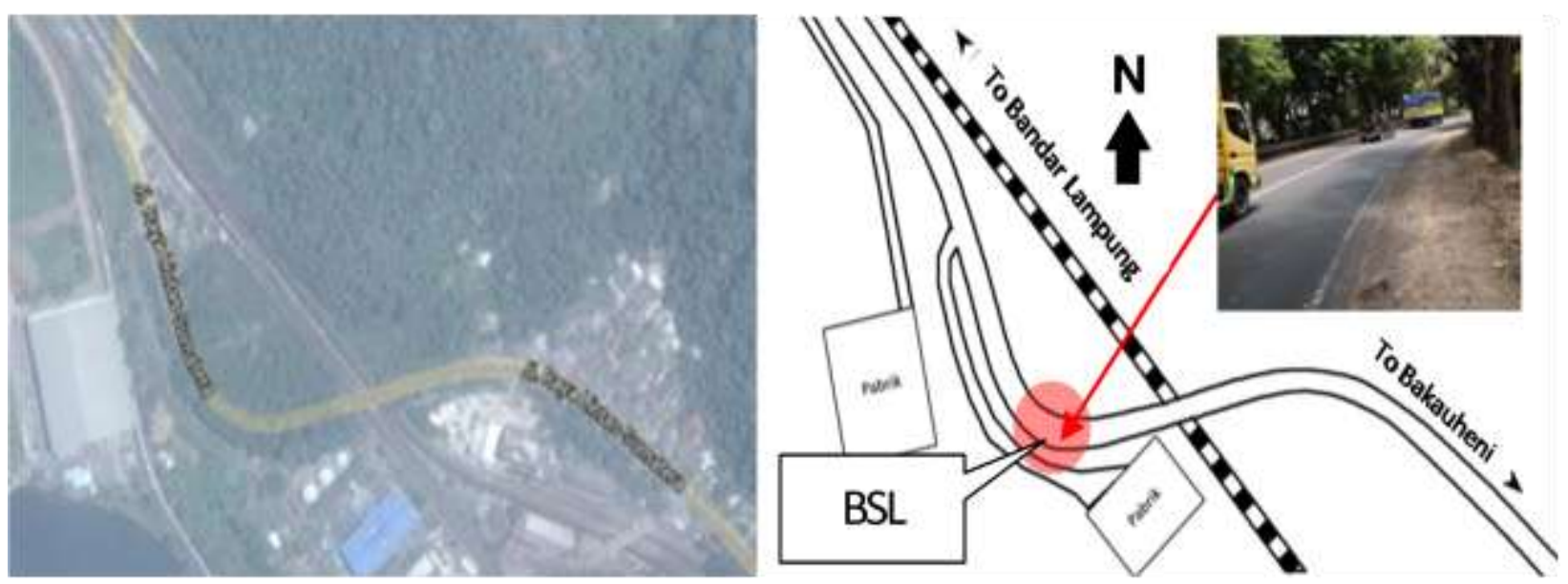

Figure 2. Example of Sketch at Jalinteng KM 14 (rank 2)
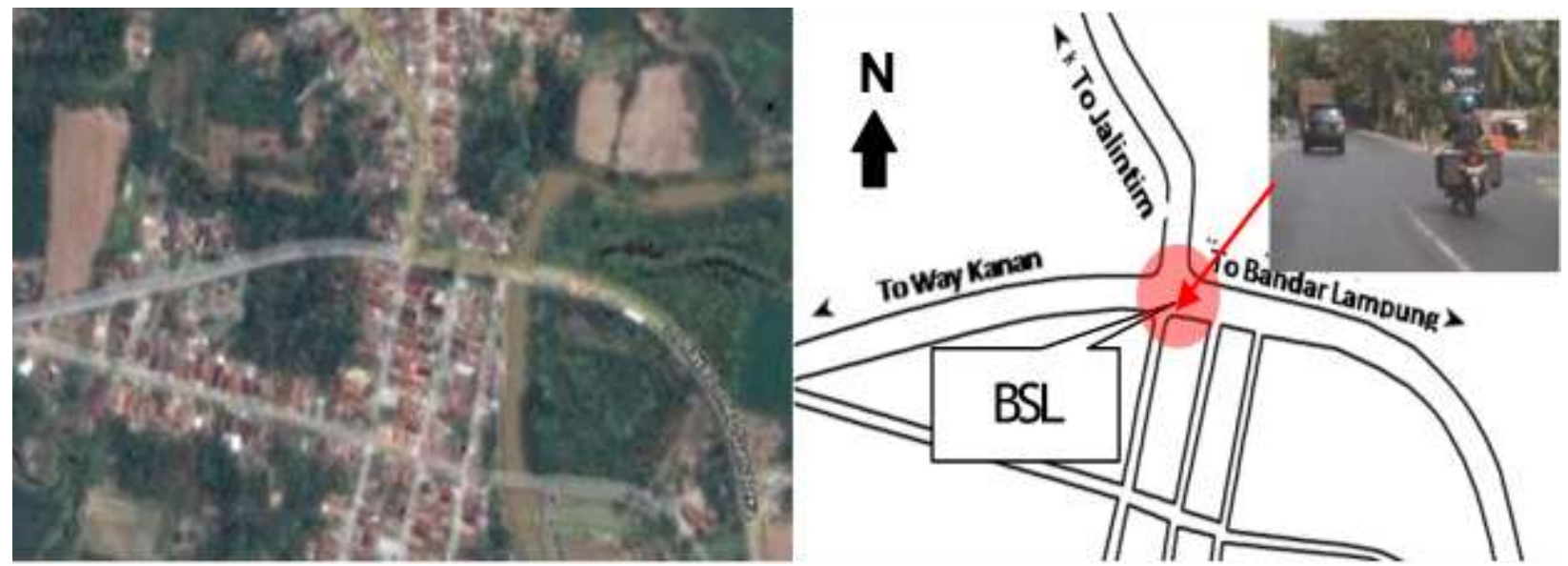

Figure 3. Example of Sketch at Jalinteng KM 72 (rank 5) 
Table 4. Examples of Alternative Treatments

\begin{tabular}{|c|c|c|c|c|c|}
\hline No. & Location & & Existing Condition & Type of Accident & Alternative Treatments \\
\hline 1 & $\begin{array}{l}\text { Jalinteng } \\
\text { KM } 14\end{array}$ & $\begin{array}{l}2) \\
3)\end{array}$ & $\begin{array}{l}\text { Road Geometric forms a } \\
\text { curve; } \\
\text { Road side consists of pit-run. } \\
\text { Sharp cornering with limited } \\
\text { visibility; } \\
\text { Good condition of road } \\
\text { pavement. }\end{array}$ & $\begin{array}{l}\quad><(\text { head-on) } \\
\text { A vehicle enforced to } \\
\text { overtake at the curve } \\
\text { resulting in a crash } \\
\text { with the opposite } \\
\text { vehicle }\end{array}$ & $\begin{array}{l}\text { 1) Installation of road signs: left curve warning } \\
(\text { Table II (1a)*) and left chevrons (Table II } \\
\left.(11 \mathrm{~d})^{*}\right)(\text { for direction towards Bandar } \\
\text { Lampung), right curve warning (Table II (1b)*) } \\
\text { and right chevrons (Table II (11e)*) (for } \\
\text { direction towards Bakauheni), } \\
\text { 2) Installation of road studs**. } \\
\text { 3) Using concrete pavement for road shoulder. }\end{array}$ \\
\hline 2 & $\begin{array}{l}\text { Jalinteng } \\
\text { KM } 72\end{array}$ & $\begin{array}{l}3) \\
4)\end{array}$ & $\begin{array}{l}\text { Road markings are unclear; } \\
\text { Three-arm junction has high } \\
\text { traffic volume on each arm; } \\
\text { Trees entering road space; } \\
\text { T-intersection signs have not } \\
\text { been installed.. }\end{array}$ & $\begin{array}{l}\quad \gg \text { (head-rear) } \\
\text { A truck ran into brak } \\
\text { failure and struck } \\
\text { another truck from } \\
\text { behind }\end{array}$ & $\begin{array}{l}\text { 1) Repainting road marking at center line and } \\
\text { side lines on each intersection leg**. } \\
\text { 2) Installing LPJU (Road Lighting)***. } \\
\text { 3) Trimming Trees. } \\
\text { 4) Improvement: Installing Warning Signs. See } \\
\left.\text { Table II }(4 \mathrm{~b} 9)^{*},(4 \mathrm{~b} 8)^{*}\right),(4 \mathrm{~b} 18)^{*} \text { and Table V } \\
(1 \mathrm{~b})^{*} \text {. }\end{array}$ \\
\hline
\end{tabular}

Note:

$>$ Head on collision

> Front-rear collision

* Peraturan Menteri Perhubungan Nomor 13 Tahun 2014 tentang Rambu Lalu Lintas [15].

** Peraturan Menteri Perhubungan Nomor 34 Tahun 2014 tentang Marka Jalan [16].

**** Peraturan Dirjen Perhubungan Darat No SK.7234/AJ.401/DRJD/2013 tentang Petunjuk Teknis Rambu Lalu Lintas [17].

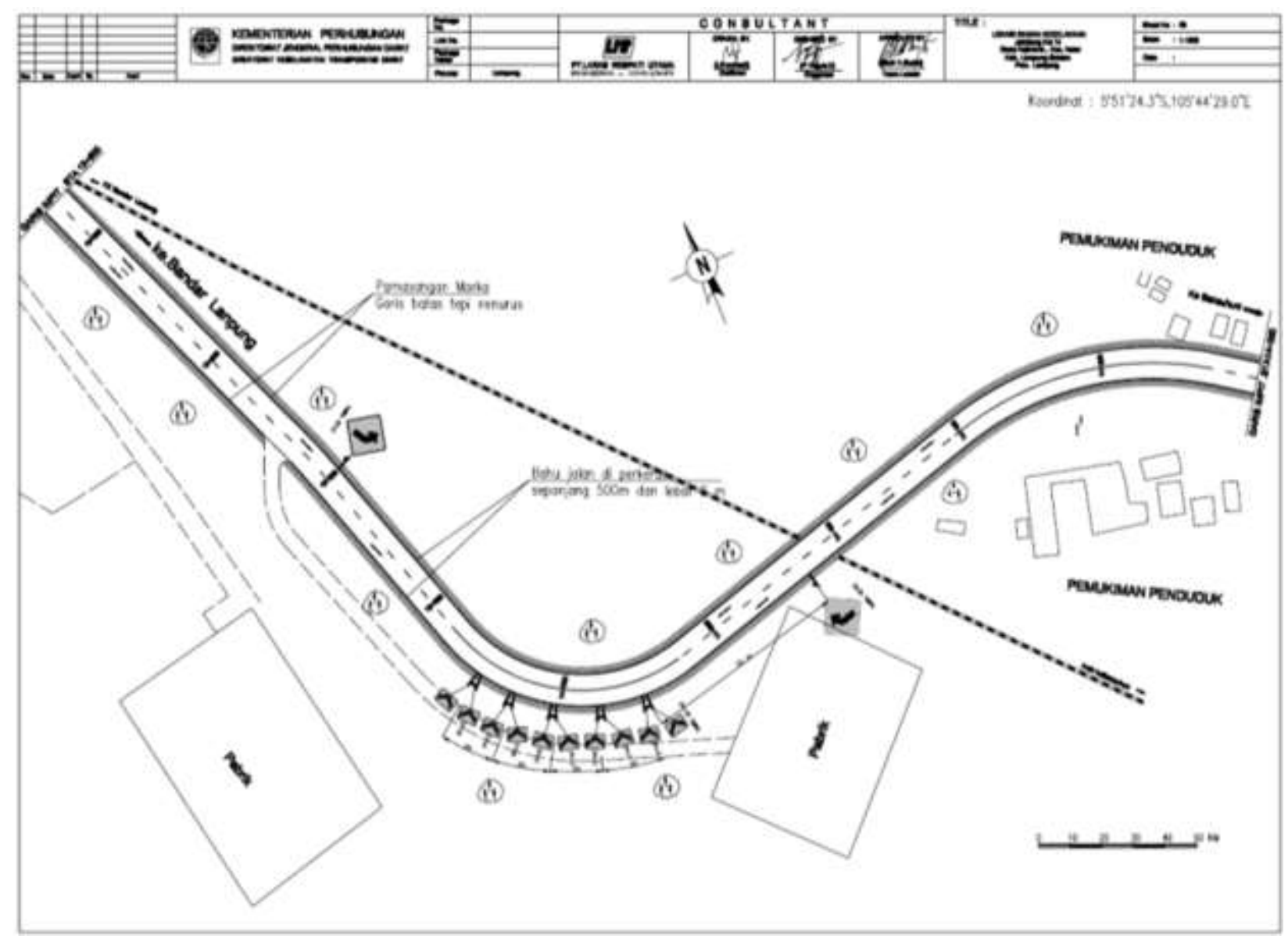

Figure 4. Example of Technical Design Drawings of BSL Treatment in Jalinteng KM 14 


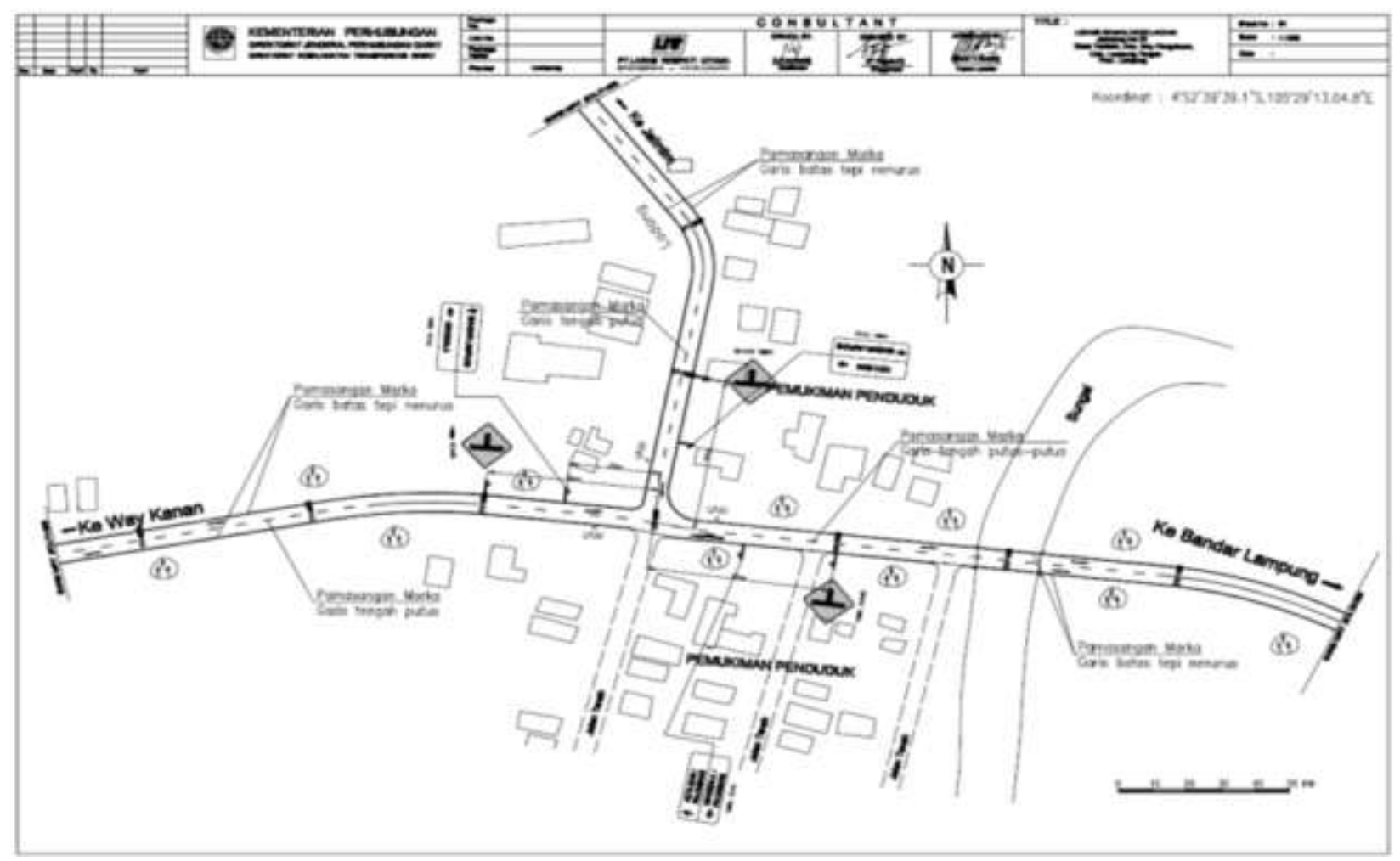

Figure 5. Example of Technical Design Drawings for BSL Treatment in Jalinteng KM 72

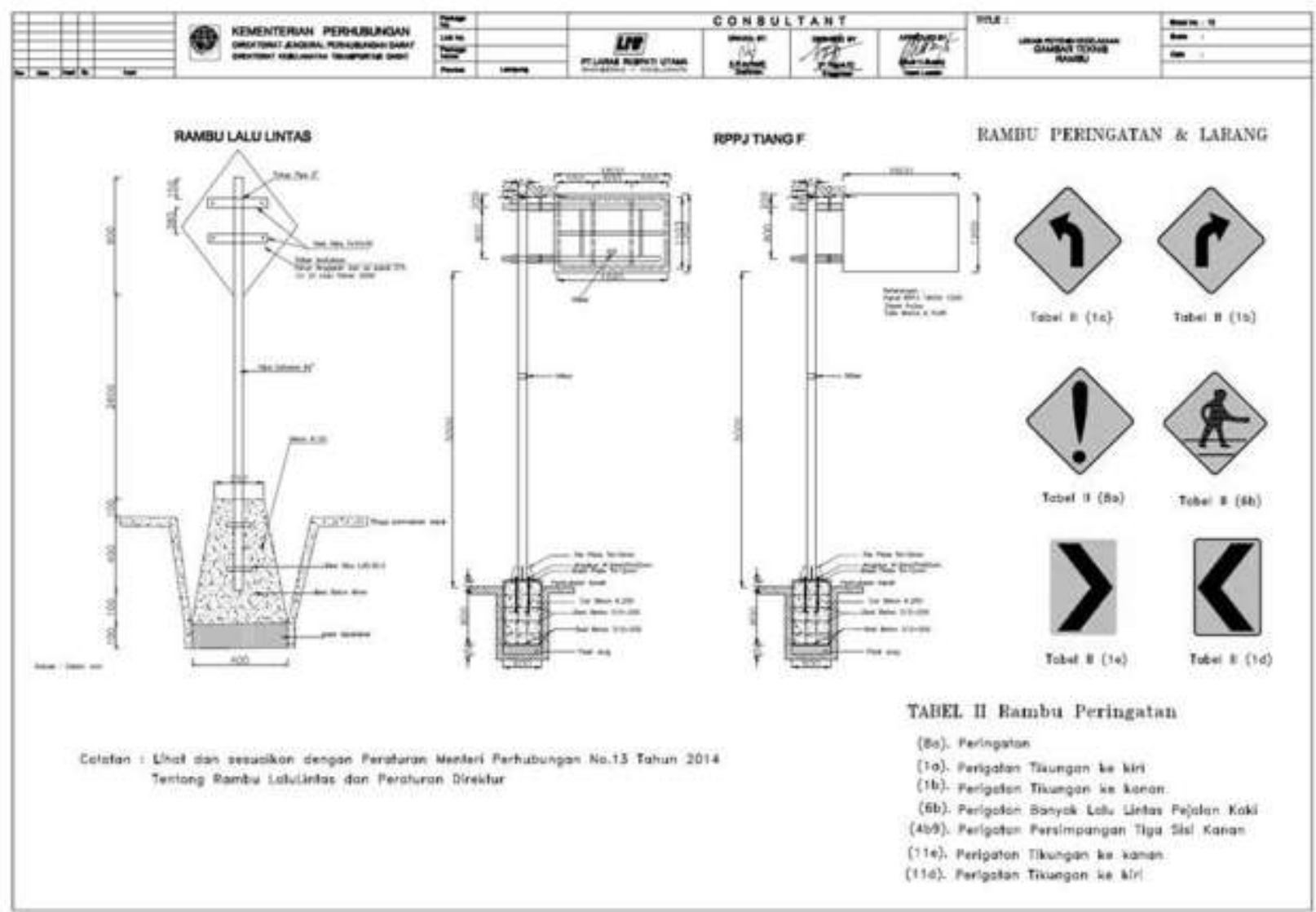

Figure 6. Example of Technical Drawing Installation of Traffic Signs for BSL Treatment [15] 


\section{Application Summary}

Based on the general procedure above, it is necessary to take the following steps in detail, namely Survey, Investigation, and Design (SID) concerning Black Spot Location (BSL). The analysis carried out on the National road in the Province of Lampung began with the collection of secondary data from the previous year. Then the determination of selected BSL was based on the number of occurrences of BSL $\geq 2$ events per location. The data from the Police Department furthermore was matched with the data from the Department of Transportation and Highways in Lampung, resulting in identification of 11 BSLs. Then EAN analysis was used to rank the 11 BSLs resulting in the five selected BSLs. Further activities and analysis of the five selected BSLs were conducting survey details, developing alternative proposal of treatment, preparing Detail Engineering Design, preparing construction cost estimates, and preparing Draft Guidelines for SID-BSL and DED. Visually, the description and analysis of the survey work are shown in Figure 7. Recording, monitoring, and evaluating activities related to SID-BSL after physical construction works are only recommendations and not included in this study.

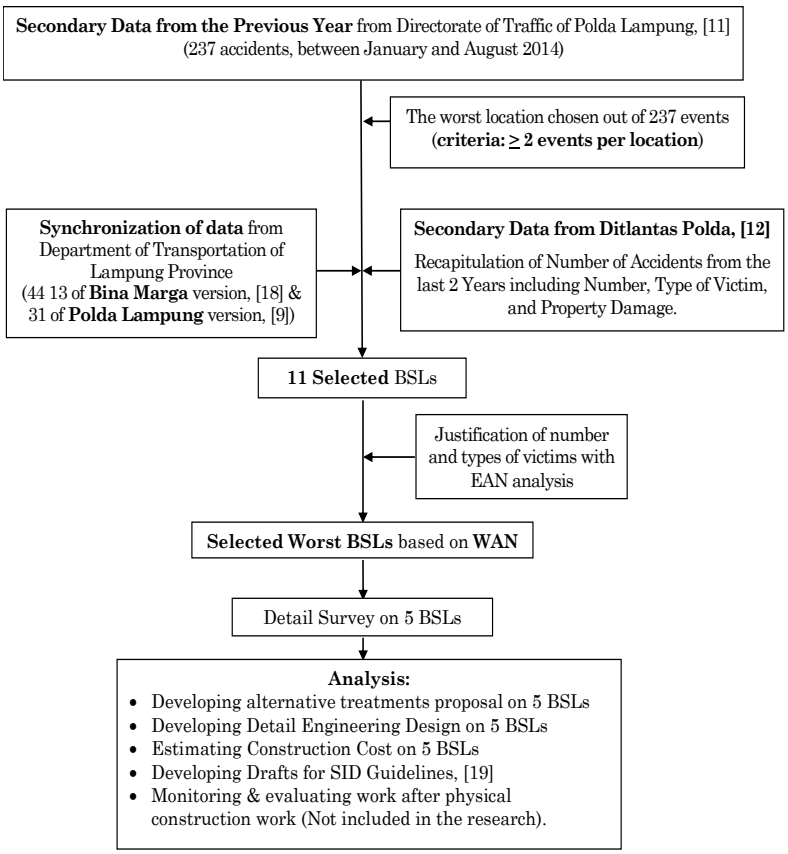

Figure 7. Flowchart of SID BSL Application Procedure in Lampung Province

\section{Conclusions and Recommendations}

\section{Conclusions}

Using the four stages of prioritization technique on the 237 events of accident on National Roads in Lampung Province, five BSLs were selected. The five
BSLs were selected by ranking of Weighted Accident Number (WAN), namely: (1) Jalinteng KM 38 (WAN = 248); (2) Jalinteng KM 21 (WAN = 202); (3) Jalinteng KM 19 (WAN = 147); (4) Jalinteng KM 72 (WAN = 142); (5) Jalinteng KM 14 (WAN = 128). The five BSLs have been analyzed for alternative treatment proposals, Detail Engineering Design (DED), and estimated construction cost requirements.

\section{Recommendations}

Based on the analysis of SID-BSL in Lampung Province, implementation of the alternative treatments on five BSLs will reduce traffic accidents. In addition, SID-BSL Guideline is expected to be immediately distributed to other provinces in Indonesia, so that Indonesia can work together to reduce the number and severity of accidents in accordance with the expectations of Presidential Instruction No. 4 of 2013, on the Decade of Action for Safety, within the period of 2011-2020. There should be adequate budget for continuous multi-year programme so that within six years, there is a 50\% decrease in the number of accidents in accordance with the Presidential Instruction.

\section{Acknowledgements}

The author would like to acknowledge and express his gratitude to Director of Directorate of Land Transportation Safety, for funding the research. The author also feels indebted to Mr. Teguh, Bandung, for his assistance. The author also appreciates all parties who have provided data and assistance in completing this study.

\section{References}

1. Direktorat Keselamatan Transportasi Darat, Draft Pedoman Survei Investigasi dan Desain Lokasi Rawan Kecelakaan, Direktorat Jenderal Perhubungan Darat, Kementerian Perhubungan, Jakarta, 2014.

2. Direktorat Keselamatan Transportasi Darat, Laporan Akhir Penyusunan Detail Engineering Design (DED) Daerah Rawan Kecelakaan di Jalan Nasional Propinsi Lampung, Direktorat Jenderal Perhubungan Darat, Kementerian Perhubungan, Jakarta, 2014.

3. Undang-Undang Republik Indonesia Nomor 22 Tahun 2009 tentang Lalu Lintas dan Angkutan Jalan.

4. Transport Research Laboratory (TRL), Accident Blackspot Investigation, Crowthorne Berkshire, United Kingdom, 1994.

5. Peraturan Menteri Perhubungan Nomor 60 Tahun 2010 tentang Organisasi dan Tata Kerja Kementerian Perhubungan. 
6. Pd T-09-2004-B, Penanganan Lokasi Rawan Kecelakaan Lalu Lintas, Departemen Permukiman dan Prasarana Wilayah, Jakarta, 2004.

7. Peraturan Pemerintah Republik Indonesia Nomor 32 Tahun 2011 tentang Manajemen dan Rekayasa, Analisis Dampak, serta Manajemen Kebutuhan Lalu Lintas.

8. Peraturan Menteri Perhubungan Nomor 75 Tahun 2013 tentang Standar Biaya Tahun 2014 di Lingkungan Kementerian Perhubungan.

9. http://ditlantaspoldalampung.web.id, Statistik Kecelakaan Lalu Lintas, accessed on August 31, 2014.

10. Priyanto, S., Biaya Kecelakaan, Workshop Peningkatan Kapasitas Pengkajian Keselamatan Ditjen Hubdat, Yogyakarta, March 28, 2011.

11. Susilo, B.H., Identifikasi dan Indikator Kinerja Keselamatan Jalan, Workshop Peningkatan Kapasitas Pengkajian Keselamatan Ditjen Hubdat, Yogyakarta, March 28, 2011.
12. Polda Lampung, Data and Information.

13. Dinas Perhubungan Provinsi Lampung, Data and Information.

14. Wedasana, A. S., Analisis Daerah Rawan Kecelakaan dan Penyusunan Database Berbasis Sistem Informasi Geografis (Studi Kasus Kota Denpasar), Udayana University, Denpasar, 2011.

15. Peraturan Menteri Perhubungan Nomor 13 Tahun 2014 tentang Rambu Lalu Lintas.

16. Peraturan Menteri Perhubungan Nomor 34 Tahun 2014 tentang Marka Jalan.

17. Peraturan Direktur Jenderal Perhubungan Darat Nomor SK.7234/AJ.401/DRJD/2013 tentang Petunjuk Teknis Perlengkapan Jalan.

18. Dinas Bina Marga Provinsi Lampung, Data and Information.

19. SNI 08 2007, Penulisan Standar Nasional Indonesia, Badan Standardisasi Nasional, Jakarta, 2007. 